\title{
The role of hepatic stellate cells in fibrotic liver diseases
}

\author{
Hye Jin Cho ${ }^{1, \#}$, Jae Young Jang ${ }^{2, \#}$ and Tae Min Kim ${ }^{1,3, *}$ \\ ${ }^{1}$ Graduate School of International Agricultural Technology, Seoul National University, Pyeongchang 25354, Korea \\ ${ }^{2}$ Department of Life Sciences, College of BioNano Technology, Gachon University, Seongnam 13120, Korea \\ ${ }^{3}$ Institutes of Green-Bio Science and Technology, Seoul National University, Pyeongchang 25354, Korea
}

Received March 24, 2020

Revised May 6, 2020

Accepted May 8, 2020

*Correspondence

Tae Min Kim

E-mail: taemin21@snu.ac.kr

ORCID

https://orcid.org/0000-0003-0015-2701

"These authors contributed equally to this work.

\begin{abstract}
Hepatic stellate cells (HSCs) play essential roles in normal and pathophysiological function in liver. In steady state, HSCs contribute to retinoid storage, immune tolerance, and extracellular matrix (ECM) homeostasis. Upon liver injury, they become activated and lead to morphological and functional changes. Studies have demonstrated that activation of HSCs by various stimuli such as toxins, microbial infection, or metabolic overload can promote the fibrotic changes in liver by production of ECM. Herein, we provide current knowledge about the basic characteristics of HSCs and the mechanism by which they are activated.
\end{abstract}

Keywords: hepatic stellate cells, liver fibrosis, liver injury

\section{INTRODUCTION}

The hallmark of fibrosis is the progressive replacement of functional parenchymal and non-parenchymal cells with myofibroblast cells that produces extracellular matrix (ECM), which lead to the formation of irreversible scar. Clinically, chronic liver diseases can be manifested by various form of pathologies, and they can increase the mortality rate of up to $45 \%$ in developed countries (Mehal et al., 2011). Accordingly, examining the underlying mechanism how fibrotic changes can be induced by HSCs would be important to better identify the potential therapeutic targets and developing novel drugs. Moreover, for understanding the cirrhosis caused by a process of hepatic fibrosis, it is essential to elucidate the fibrotic change in liver (Greenbaum and Wells, 2011). Liver fibrosis can be defined as an excess of ECM due to chronic inflammation, and eventually this lead to cirrhotic change due to the deformation of the interstitial structure and the reduction in the number of liver cells (Bin et al., 2012). Previous studies have demonstrated that the most typical cells involved in liver fibrosis are hepatic cells, Kupffer cells, and endothelial cells (Kolios et al., 2006). In particular, hepatic stellate cells (HSCs) has been shown to be the main source of ECMs including collagen (Khomich et al., 2019).

\section{HEPATIC STELLATE CELLS (HSCs)}

In 1876, HSCs were first discovered as dark area stained with gold chloride, and a German scientist Carl von Kupffer named them as stellate cells (Shang et al., 2018). Histologically, their multiple lipid droplets can be observed in the Disse space, which lies between the sinusoidal endothelial cell and the hepatocytes. It has been reported that they are rich in vitamin A (thus it is called vitamin A cell), fat, or perisinusoidal chemical (Senoo et al., 2017). The HSCs are in close contact with the liver and endothelium cell (van Til et al., 2005). It accounts for 
about 5 to 8 percent of the population of entire liver cells, and is linked to the end of the autonomous nerve fiber (Jensen et al., 2013). HSCs is considered to be myogenic origin, because they have the characteristics of muscular tissue such as desmin and $\alpha$-smooth muscle actin (Hwang et al., 2004). When activated by various stimuli, HSCs transforms into a myofibroblast-like phenotype, via several biological events including increased contractibility, the production of various ECMs including collagen type I and II, and de novo expression of $\alpha$-SMA (Bin et al., 2012). Conventionally, HSCs are investigated in vitro to examine the anti-fibrotic role of drug candidates because they can be naturally activated without any treatment in culture vessels after being isolated from the liver (Higashi et al., 2017).

\section{CHARACTERIZATION OF HEPATIC STELLATE CELLS}

The developmental origin of stellate cells has been controversial. Among various tissues, they may be originated from either endoderm or the septum transversum (Asahina et al., 2011; Chan et al., 2013). In support of the latter, HSCs express the mesodermal transcriptional factor Foxf1, which is specifically found in the septum transversum during liver development (Agamova et al., 1987). Besides, it has been suggested that HSCs and hepatoblasts come from common endodermal origin, based on the results of expression of some proteins of cytokeratin family in both cell types (Kiassov et al., 1995; Levy et al., 1999)

\section{Markers of HSCs}

Although no specific single marker for HSCs is available, several potential markers for HSCs have been identified. Most commonly, activated HSCs express desmin, glial fibrillary acidic protein (GFAP), and $\alpha$-SMA in rodent species. Among cytoskeletal proteins, desmin has been widely used for identifying HSCs (Yokoi et al., 1984). Alpha-smooth muscle actin ( $\alpha$-SMA) has also been used as a reliable marker for HSC activation, since this protein is only resident in the vascular smooth muscle cells and portal myofibroblasts (Schmitt-Gräff et al., 1991; Levy et al., 1999).

Based on the fact that HSCs are in close contact with nerve endings, neurotrophin receptors was recognized in activated HSCs (Cassiman et al., 2001), as shown in the functional studies confirming their neurohumoral responsiveness (Oben et al., 2004; Roskams et al., 2004; Friedman, 2008). In rodent studies, HSCs have been found to express GFAP (Gard et al., 1985), nerve growth factor receptor (NGFRp75), and neurotrophic receptor tyrosine kinase receptor 3 (NTRK3) (Trim et al., 2000; Cassiman et al., 2001; Cassiman et al., 2002). NTRK3 is expressed in HSCs in normal and pathologic conditions, and depending on the nature of stimuli, it is also expressed in vascular smooth muscle cells. Other markers related to neural origin include neural cell adhesion molecule (N-CAM) (Nakatani et al., 1996) and Neurotrophin-3 (NT-3) (Cassiman et al., 2002).

Potentially, proteins involved in retinol metabolism have been examined for their specificity on activated HSCs. Cellular retinol binding protein-1 (CRBP-1) is a carrier protein of intracellular retinol. Although not exclusive, immunohistochemical analysis revealed that CRBP-1 was weakly expressed in the cytoplasm of hepatocytes, while its expression was much more intense in HSCs in rat (Kato et al., 1984). Other study has shown that cytoglobin/stellate cell activation-associated protein (CYGB/ STAP) is expressed in rat HSCs, as supported by results of proteome analysis (Kristensen et al., 2000). It is notable that although Cygb is expressed in the quiescent HSCs, its expression become more abundant when these cells had been activated in fibrotic liver tissues. In addition, other hepatic cells such as hepatocytes and bile-duct epithelial cells, as well as non-parenchymal macrophages and vascular endothelial cells, are negative for Cygb immunostaining. Lecithin retinol acyltransferase (LRAT) is involved in production of all retinyl ester in the liver, and experimental results showed that it is essential for the formation of lipid droplets, and it was recognized as a marker for HSCs (Levy et al., 1999; De Minicis et al., 2007; Blaner et al., 2009). Fibroblast activation protein (FAP) is a cell membrane-bound surface protease of the prolyloligopeptidase gene family that are expressed within tissues undergoing substantial remodeling. Both mRNA and protein of FAP were detected in cirrhotic liver, as shown by its colocalization with $\alpha$-SMA in hepatic tissues and in isolated hepatocytes (Levy et al., 1999; Levy et al., 2002). Importantly, its expression reflected the progression of hepatic fibrotic changes. Among membrane receptors, platelet-derived growth factor receptor $\beta$ (PDGFR $\beta$ ) was first identified as a marker for HSC, although its expres- 
sion was not exclusively detected only in activated HSCs in rodents. Finally, a co-inhibitory protein programmed death ligand-1 (PDL1) was expressed specifically on activated HSCs (Levy et al., 2002).

\section{Activation of HSC}

There are various ways in which HSC is activated. It has been suggested that quiescent HSCs become activated when they suffer cellular injuries such as oxidative stress, cholesterol stimulation, endoplasmic reticulum (ER) stress, loss of retinoids, and autophagy (Tsuchida and Friedman, 2017) (Fig. 1). When the ECM deposition increase, the progression of fibrosis occurs. Oxidative stress is caused by production of intermediate electron carriers that may be resulted from metabolic overload from mitochondrial dysfunction. In liver, it was shown that reactive oxygen species (ROS) produced by damaged liver cells provides a paracrine signal for HSCs activation (Novo et al., 2011).

Studies also demonstrated that free cholesterol activates HSC. For example, if cholesterol is added to high fat or methionine- and choline-deficient (MCD) diet in animals, free cholesterol accumulates in HSC and thus accelerates liver fibrosis (Tomita et al., 2014). In addition, mice ingested with a high cholesterol diet after treatment of bile duct ligation (BDL) or carbon tetrachloride $\left(\mathrm{CCl}_{4}\right)$ induced liver fibrosis via activation of HSCs. Mechanistically, accumulation of cholesterol in HSC increased the activation of TGF $\beta$-induced activation by upregulating and stabilizing Toll-like receptor 4 (TLR4), which led to a reduction in a TGF $\beta$ pseudo receptor BAMBI (bone morphogenetic protein and activin membrane bound inhibitor) (Teratani et al., 2012).
Another mechanism by which HSCs are activated is ER stress, which leads to an increase in both autophagy and induces fibrogenic genes like SMAD2. The levels of SMAD2 messenger RNA are increased by ER stress by decreasing levels of miR-18a, which is an inhibitor of SMAD2. ER stress-activated PKR-like endoplasmic reticulum kinase (PERK) phosphorylates heterogeneous nuclear ribonucleoprotein A1 (HNRNPA1) required for the maturation of primary miR-18a (Asahina et al., 2011).

Autophagy is also involved in HSC activation. It was demonstrated that autophagy promotes HSC activation by producing retinyl esters-derived fatty acids in cytoplasm (Thoen et al., 2011). Another study showed that mice deficient in the autophagy-related protein 7 (ATG7) in HSCs had a significantly reduced fibrogenic lesions and ECM accumulations in response to $\mathrm{CCl}_{4}$-induced liver fibrosis model (Hernández-Gea et al., 2012).

Liver plays multiple roles such as nutrient and drug metabolism, energy storage, production of plasma protein, hormones, and cholesterol. Other function includes immunological reactions (antigen presentation and removal of foreign materials) and bile production (Weiskirchen and Tacke, 2014). Accordingly, many cell types are involved in the normal physiology of this organ, and the function HSCs are also prone to be affected by neighboring cells. For example, injury in hepatocytes, e.g., viral infection and non-alcoholic steatohepatitis (NASH), can cause inflammation and fibrotic progression of HSCs. Studies have demonstrated that various local mediators including reactive oxygen species (ROS) (Agamova et al., 1987; Machado et al., 2015), Hedgehog (Hh) ligands (Machado et al., 2015) and nucleotides (Vaughn et al., 2014) facilitate this

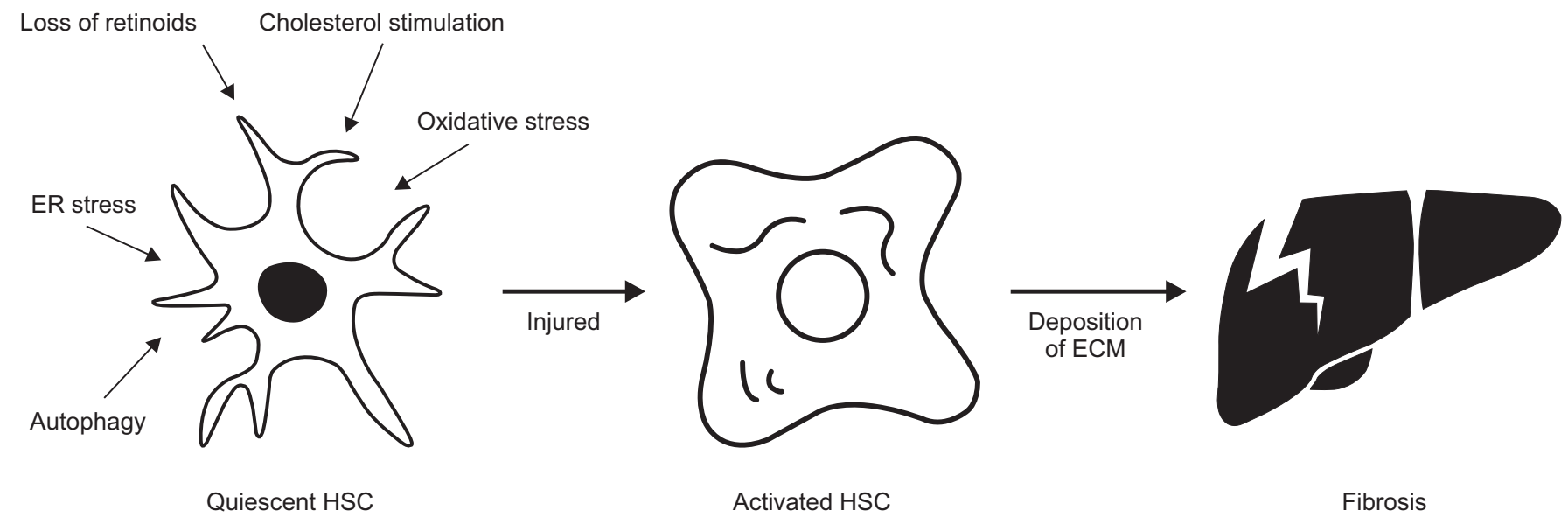

Fig. 1. Schematic diagram showing various etiologies of HSC activation. 
process. Macrophage, which is also a subset of non-parenchymal cells in the liver, can be classified into tissueresident macrophages, monocyte-derived macrophages and Kupffer cells (Blériot and Ginhoux, 2019). Kupffer cells constitute the majority of resident macrophages in the body, and play a major homeostatic role in the liver (Wiegard et al., 2005; Kisseleva and Brenner, 2006). In response to injury, bone-marrow derived monocytes react upon inflammatory cues, and locate to liver, and then differentiate into macrophages. Upon arrival to the liver, macrophages secrete cytokines and chemokines including transforming growth factor beta (TGF $\beta$ ), platelet-derived growth factor (PDGF), tumor necrosis factor (TNF), interleukin 1 beta (IL-1 $\beta$ ), monocyte chemoattractant protein-1 (MCP1), C-C motif chemokine ligand 3 and 5 (CCL3, CCL5). TNF and IL- $1 \beta$ affect the activated HSCs, and promote survival through NF- $\mathrm{KB}$ activation (Pradere et al., 2013). Macrophages exhibit anti-fibrotic function via secreting fibrolytic matrix metalloproteinases (MMPs) including MMP-12 and -13 (Taimr et al., 2003; Ramachandran et al., 2012). In normal physiology, liver sinusoidal endothelial cells (LSEC) inhibit HSC activation and stimulate the reversion of activated HSCs to quiescent stage through vascular endothelial growth factor (VEGF)-stimulated nitric oxide (NO) production (Deleve et al., 2008).

Other than liver-derived cells, several lymphocytes can regulate HSC activation. Natural killer cells possess antifibrotic properties, including disruption of activated HSCs by secreting interferon gamma (IFN $\gamma$ ) (Jeong et al., 2008; Jeong et al., 2011). In addition, NK cells induce the apoptosis in HSCs by expressing death receptor ligands such as Tumor necrosis factor-related apoptosis-inducing ligand (TRAIL) and Fas ligand (FASL) (also known as TNF ligand superfamily member 6) (Glässner et al., 2012). Besides, natural killer cells supports the clearance of activated senescent HSCs, thereby facilitating the resolution of fibrosis (Krizhanovsky et al., 2008). Although not well established, natural killer T (NKT) cells are shown to be functionally related with HSC activation and liver fibrosis (Wang and Yin, 2015). Similar to natural killer cells, NKT cells directly induce the death of activated HSCs by secreting IFN $\gamma$ (Park et al., 2009). More early study using Bcell deficient mice has revealed that the hepatic fibrotic lesion was decreased, suggesting a profibrogenic function of B cells (Novobrantseva et al., 2005). Other than lymphocytes, platelets are a major source of PDGF $\beta$ and TGF $\beta$, which have potential to stimulate HSCs and resulting tissue fibrosis in a wide range of liver diseases including alcoholic liver disease (ALD) and hepatitis B and C, and NASH (Nowatari et al., 2014; Kurokawa et al., 2016).

\section{FUTURE PERSPECTIVES}

HSCs have been recognized as one of the major players in developing fibrotic liver diseases. The role of HSCs in the progression of hepatic fibrosis caused by chronic stimuli are being explored in various experimental models. Since developmental events can be recapitulated in pathological conditions, a better understanding on the origin of HSCs during embryogenesis would provide us with important insights about the biological mechanisms underlying their activation and downstream events. To this end, genetic knockout studies of key regulatory genes using Clustered Regularly Interspaced Short Palindromic Repeats (CRISPR)/Cas9 (Martufi et al., 2019), or cellspecific ablation techniques would be ideal to identify the regulatory mechanisms of HSCs.

\section{CONFLICTS OF INTEREST}

No potential conflict of interest relevant to this article was reported.

\section{ACKNOWLEDGEMENTS}

This study was supported by the Research Resettlement Fund for the New Faculty of Seoul National University, No. 1403-20180039 (T.M.K.). This work was also supported by Basic Science Research Program through the National Research Foundation of Korea (NRF) funded by the Ministry of Education (2018R1D1A1A02085481) (T.M.K.). We also thank Institutes of Green-Bio Science and Technology, SNU, for providing an undergraduate internship training program (J.Y.J.).

\section{AUTHOR CONTRIBUTIONS}

Conceptualization: H.J.C., J.Y.J., T.M.K.

Funding Acquisition: T.M.K.

Investigation: H.J.C., J.Y.J.

Writing - original draft: H.J.C., J.Y.J., T.M.K.

Writing - review \& editing: H.J.C., J.Y.J., T.M.K. 


\section{AUTHOR'S POSITION AND ORCID NO.}

\author{
HJ Cho, M.S Student, \\ https://orcid.org/0000-0003-1804-117X \\ JY Jang, B.S Student, \\ https://orcid.org/0000-0003-2463-7746 \\ TM Kim, Assistant Professor, \\ https://orcid.org/0000-0003-0015-2701
}

\section{REFERENCES}

Agamova KA, Starinskiı̌ VV, Nevskaia EA, Gladunova ZD, Nikitina NI. 1987. [The role of cytological studies in evaluating the severity of dysplasia during prophylactic gynecological examinations (cooperative study)]. Vopr. Onkol. 33:53-57. Russian.

Asahina K, Zhou B, Pu WT, Tsukamoto H. 2011. Septum transversum-derived mesothelium gives rise to hepatic stellate cells and perivascular mesenchymal cells in developing mouse liver. Hepatology 53:983-995.

Bin WT, Ma LM, Xu Q, Shi XL. 2012. Embryonic hepatocyte transplantation for hepatic cirrhosis: efficacy and mechanism of action. World J. Gastroenterol. 18:309-322.

Blaner WS, O'Byrne SM, Wongsiriroj N, Kluwe J, D’Ambrosio DM, Jiang H, Schwabe RF, Hillman EM, Piantedosi R, Libien J. 2009. Hepatic stellate cell lipid droplets: a specialized lipid droplet for retinoid storage. Biochim. Biophys. Acta 1791:467-473.

Blériot C and Ginhoux F. 2019. Understanding the heterogeneity of resident liver macrophages. Front. Immunol. 10:2694.

Cassiman D, Denef C, Desmet VJ, Roskams T. 2001. Human and rat hepatic stellate cells express neurotrophins and neurotrophin receptors. Hepatology 33:148-158.

Cassiman D, Libbrecht L, Desmet V, Denef C, Roskams T. 2002. Hepatic stellate cell/myofibroblast subpopulations in fibrotic human and rat livers. J. Hepatol. 36:200-209.

Chan KM, Fu YH, Wu TJ, Hsu PY, Lee WC. 2013. Hepatic stellate cells promote the differentiation of embryonic stem cellderived definitive endodermal cells into hepatic progenitor cells. Hepatol. Res. 43:648-657.

De Minicis S, Seki E, Uchinami H, Kluwe J, Zhang Y, Brenner DA, Schwabe RF. 2007. Gene expression profiles during hepatic stellate cell activation in culture and in vivo. Gastroenterology 132:1937-1946.

Deleve LD, Wang X, Guo Y. 2008. Sinusoidal endothelial cells prevent rat stellate cell activation and promote reversion to quiescence. Hepatology 48:920-930.

Friedman SL. 2008. Hepatic stellate cells: protean, multifunctional, and enigmatic cells of the liver. Physiol. Rev. 88:125-172.

Gard AL, White FP, Dutton GR. 1985. Extra-neural glial fibrillary acidic protein (GFAP) immunoreactivity in perisinusoidal stellate cells of rat liver. J. Neuroimmunol. 8:359-375.

Glässner A, Eisenhardt M, Krämer B, Körner C, Coenen M, Sauerbruch T, Spengler U, Nattermann J. 2012. NK cells from
HCV-infected patients effectively induce apoptosis of activated primary human hepatic stellate cells in a TRAIL-, FasLand NKG2D-dependent manner. Lab. Invest. 92:967-977.

Greenbaum LE and Wells RG. 2011. The role of stem cells in liver repair and fibrosis. Int. J. Biochem. Cell Biol. 43:222-229.

Hernández-Gea V, Ghiassi-Nejad Z, Rozenfeld R, Gordon R, Fiel MI, Yue Z, Czaja MJ, Friedman SL. 2012. Autophagy releases lipid that promotes fibrogenesis by activated hepatic stellate cells in mice and in human tissues. Gastroenterology 142:938-946.

Higashi T, Friedman SL, Hoshida Y. 2017. Hepatic stellate cells as key target in liver fibrosis. Adv. Drug Deliv. Rev. 121:27-42.

Hwang JH, Yuk SH, Lee JH, Lyoo WS, Ghil SH, Lee SS, Khang IG, Paik SY, Lee JY. 2004. Isolation of muscle derived stem cells from rat and its smooth muscle differentiation [corrected]. Mol. Cells 17:57-61.

Jensen KJ, Alpini G, Glaser S. 2013. Hepatic nervous system and neurobiology of the liver. Compr. Physiol. 3:655-665.

Jeong WI, Park O, Gao B. 2008. Abrogation of the antifibrotic effects of natural killer cells/interferon-gamma contributes to alcohol acceleration of liver fibrosis. Gastroenterology 134:248-258.

Jeong WI, Park O, Suh YG, Byun JS, Park SY, Choi E, Kim JK, Ko H, Wang H, Miller AM, Gao B. 2011. Suppression of innate immunity (natural killer cell/interferon- $\gamma$ ) in the advanced stages of liver fibrosis in mice. Hepatology 53:1342-1351.

Kato M, Kato K, Goodman DS. 1984. Immunocytochemical studies on the localization of plasma and of cellular retinolbinding proteins and of transthyretin (prealbumin) in rat liver and kidney. J. Cell Biol. 98:1696-1704.

Khomich O, Ivanov AV, Bartosch B. 2019. Metabolic hallmarks of hepatic stellate cells in liver fibrosis. Cells 9:24.

Kiassov AP, Van Eyken P, van Pelt JF, Depla E, Fevery J, Desmet VJ, Yap SH. 1995. Desmin expressing nonhematopoietic liver cells during rat liver development: an immunohistochemical and morphometric study. Differentiation 59:253-258.

Kisseleva T and Brenner DA. 2006. Hepatic stellate cells and the reversal of fibrosis. J. Gastroenterol. Hepatol. 21 Suppl 3:S84-S87.

Kolios G, Valatas V, Kouroumalis E. 2006. Role of Kupffer cells in the pathogenesis of liver disease. World J. Gastroenterol. 12:7413-7420.

Kristensen DB, Kawada N, Imamura K, Miyamoto Y, Tateno C, Seki S, Kuroki T, Yoshizato K. 2000. Proteome analysis of rat hepatic stellate cells. Hepatology 32:268-277.

Krizhanovsky V, Yon M, Dickins RA, Hearn S, Simon J, Miething C, Yee H, Zender L, Lowe SW. 2008. Senescence of activated stellate cells limits liver fibrosis. Cell 134:657-667.

Kurokawa T, Zheng YW, Ohkohchi N. 2016. Novel functions of platelets in the liver. J. Gastroenterol. Hepatol. 31:745-751.

Levy MT, McCaughan GW, Abbott CA, Park JE, Cunningham AM, Müller E, Rettig WJ, Gorrell MD. 1999. Fibroblast activation protein: a cell surface dipeptidyl peptidase and gelatinase expressed by stellate cells at the tissue remodelling interface in human cirrhosis. Hepatology 29:1768-1778.

Levy MT, McCaughan GW, Marinos G, Gorrell MD. 2002. Intra- 
hepatic expression of the hepatic stellate cell marker fibroblast activation protein correlates with the degree of fibrosis in hepatitis $C$ virus infection. Liver 22:93-101.

Machado MV, Michelotti GA, Pereira Tde A, Boursier J, Kruger L, Swiderska-Syn M, Karaca G, Xie G, Guy CD, Bohinc B, Lindblom KR, Johnson E, Kornbluth S, Diehl AM. 2015. Reduced lipoapoptosis, hedgehog pathway activation and fibrosis in caspase-2 deficient mice with non-alcoholic steatohepatitis. Gut 64:1148-1157.

Martufi M, Good RB, Rapiteanu R, Schmidt T, Patili E, Tvermosegaard K, New M, Nanthakumar CB, Betts J, Blanchard AD, Maratou K. 2019. Single-step, high-efficiency CRISPRCas9 genome editing in primary human disease-derived fibroblasts. CRISPR J. 2:31-40.

Mehal WZ, Iredale J, Friedman SL. 2011. Scraping fibrosis: expressway to the core of fibrosis. Nat. Med. 17:552-553.

Nakatani K, Seki S, Kawada N, Kobayashi K, Kaneda K. 1996. Expression of neural cell adhesion molecule (N-CAM) in perisinusoidal stellate cells of the human liver. Cell Tissue Res. 283:159-165.

Novo E, Busletta C, Bonzo LV, Povero D, Paternostro C, Mareschi K, Ferrero I, David E, Bertolani C, Caligiuri A, Cannito S, Tamagno E, Compagnone A, Colombatto S, Marra F, Fagioli F, Pinzani M, Parola M. 2011. Intracellular reactive oxygen species are required for directional migration of resident and bone marrow-derived hepatic pro-fibrogenic cells. J. Hepatol. 54:964-974.

Novobrantseva TI, Majeau GR, Amatucci A, Kogan S, Brenner I, Casola S, Shlomchik MJ, Koteliansky V, Hochman PS, Ibraghimov A. 2005. Attenuated liver fibrosis in the absence of B cells. J. Clin. Invest. 115:3072-3082.

Nowatari T, Murata S, Fukunaga K, Ohkohchi N. 2014. Role of platelets in chronic liver disease and acute liver injury. Hepatol. Res. 44:165-172.

Oben JA, Roskams T, Yang S, Lin H, Sinelli N, Torbenson M, Smedh U, Moran TH, Li Z, Huang J, Thomas SA, Diehl AM. 2004. Hepatic fibrogenesis requires sympathetic neurotransmitters. Gut 53:438-445.

Park O, Jeong WI, Wang L, Wang H, Lian ZX, Gershwin ME, Gao B. 2009. Diverse roles of invariant natural killer T cells in liver injury and fibrosis induced by carbon tetrachloride. Hepatology 49:1683-1694.

Pradere JP, Kluwe J, De Minicis S, Jiao JJ, Gwak GY, Dapito DH, Jang MK, Guenther ND, Mederacke I, Friedman R, Dragomir AC, Aloman C, Schwabe RF. 2013. Hepatic macrophages but not dendritic cells contribute to liver fibrosis by promoting the survival of activated hepatic stellate cells in mice. Hepatology 58:1461-1473.

Ramachandran P, Pellicoro A, Vernon MA, Boulter L, Aucott RL, Ali A, Hartland SN, Snowdon VK, Cappon A, GordonWalker TT, Williams MJ, Dunbar DR, Manning JR, van Rooijen N, Fallowfield JA, Forbes SJ, Iredale JP. 2012. Differential Ly-6C expression identifies the recruited macrophage phenotype, which orchestrates the regression of murine liver fibrosis. Proc. Natl. Acad. Sci. U. S. A. 109:E3186-E3195.

Roskams T, Cassiman D, De Vos R, Libbrecht L. 2004. Neuro- regulation of the neuroendocrine compartment of the liver. Anat. Rec. A Discov. Mol. Cell. Evol. Biol. 280:910-923.

Schmitt-Gräff A, Krüger S, Bochard F, Gabbiani G, Denk H. 1991. Modulation of alpha smooth muscle actin and desmin expression in perisinusoidal cells of normal and diseased human livers. Am. J. Pathol. 138:1233-1242.

Senoo H, Mezaki Y, Fujiwara M. 2017. The stellate cell system (vitamin A-storing cell system). Anat. Sci. Int. 92:387-455.

Shang L, Hosseini M, Liu X, Kisseleva T, Brenner DA. 2018. Human hepatic stellate cell isolation and characterization. J. Gastroenterol. 53:6-17.

Taimr P, Higuchi H, Kocova E, Rippe RA, Friedman S, Gores GJ. 2003. Activated stellate cells express the TRAIL receptor-2/ death receptor-5 and undergo TRAIL-mediated apoptosis. Hepatology 37:87-95.

Teratani T, Tomita K, Suzuki T, Oshikawa T, Yokoyama H, Shimamura K, Tominaga S, Hiroi S, Irie R, Okada Y, Kurihara C, Ebinuma H, Saito H, Hokari R, Sugiyama K, Kanai T, Miura S, Hibi T. 2012. A high-cholesterol diet exacerbates liver fibrosis in mice via accumulation of free cholesterol in hepatic stellate cells. Gastroenterology 142:152-164.e10.

Thoen LF, Guimarães EL, Dollé L, Mannaerts I, Najimi M, Sokal E, van Grunsven LA. 2011. A role for autophagy during hepatic stellate cell activation. J. Hepatol. 55:1353-1360.

Tomita K, Teratani T, Suzuki T, Shimizu M, Sato H, Narimatsu K, Okada Y, Kurihara C, Irie R, Yokoyama H, Shimamura K, Usui S, Ebinuma H, Saito H, Watanabe C, Komoto S, Kawaguchi A, Nagao S, Sugiyama K, Hokari R, Kanai T, Miura S, Hibi T. 2014. Free cholesterol accumulation in hepatic stellate cells: mechanism of liver fibrosis aggravation in nonalcoholic steatohepatitis in mice. Hepatology 59:154-169.

Trim N, Morgan S, Evans M, Issa R, Fine D, Afford S, Wilkins B, Iredale J. 2000. Hepatic stellate cells express the low affinity nerve growth factor receptor p75 and undergo apoptosis in response to nerve growth factor stimulation. Am. J. Pathol. 156:1235-1243.

Tsuchida T, Friedman SL. 2017. Mechanisms of hepatic stellate cell activation. Nat. Rev. Gastroenterol. Hepatol. 14:397-411.

van Til NP, Markusic DM, van der Rijt R, Kunne C, Hiralall JK, Vreeling H, Frederiks WM, Oude-Elferink RP, Seppen J. 2005. Kupffer cells and not liver sinusoidal endothelial cells prevent lentiviral transduction of hepatocytes. Mol. Ther. 11:26-34.

Vaughn BP, Robson SC, Longhi MS. 2014. Purinergic signaling in liver disease. Dig. Dis. 32:516-524.

Wang H and Yin S. 2015. Natural killer T cells in liver injury, inflammation and cancer. Expert Rev. Gastroenterol. Hepatol. 9:1077-1085.

Weiskirchen R and Tacke. 2014. Cellular and molecular functions of hepatic stellate cells in inflammatory responses and liver immunology. Hepatobiliary Surg. Nutr. 3:344-363.

Wiegard C, Frenzel C, Herkel J, Kallen KJ, Schmitt E, Lohse AW. 2005. Murine liver antigen presenting cells control suppressor activity of CD4+CD25+ regulatory T cells. Hepatology 42:193-199.

Yokoi Y, Namihisa T, Kuroda H, Komatsu I, Miyazaki A, Watanabe S, Usui K. 1984. Immunocytochemical detection of desmin in fat-storing cells (Ito cells). Hepatology 4:709-714. 